\title{
Goed werkgeverschap en goed werknemerschap: een bijzondere arbeidsrelatie
}

\author{
Rien Huiskamp, Erik Jan van Dalen, Rob Gründemann en Ruben Jongkind*
}

TNO voert in het kader van het kennisinvesteringsprogramma op het terrein van het ministerie van Sociale Zaken en Werkgelegenheid een vierjarig onderzoeksprogramma uit naar goed werkgeverschap en goed werknemerschap. De doelstelling is tweeledig. In de eerste plaats theoretisch: het empirisch toetsbaar maken van de begrippen met het oog op nader onderzoek. In de tweede plaats praktisch: denk aan het ontwikkelen van een 'microfundering van het poldermodel' door het stimuleren van 'volwassen' arbeidsverhoudingen in de bedrijven en instellingen, in het bijzonder in het overleg tussen medewerker en direct leidinggevende.

In deze bijdrage richten wij ons op de eerste doelstelling. We willen een brug slaan tussen wetenschappelijke benaderingen en het normatieve concept van goed werkgeverschap en goed werknemerschap. Het bijvoeglijke naamwoord 'goed' spreekt immers boekdelen. In dit artikel wordt in de eerste plaats economische, sociologische en psychologische literatuur onderzocht op theorieën en concepten die licht werpen op het verschijnsel goed werkgeverschap en goed werknemerschap. Denk bijvoorbeeld aan agency-theorie, het psychologische contract, vertrouwen en 'organisational citizenship behaviour'. In de tweede plaats wordt een conceptueel model ontwikkeld met twee uitwerkingen: een voor goed werkgeverschap en een voor goed werknemerschap. De basis voor dit model is de arbeidsrelatie. Met het model proberen wij onder meer de verwachtingen en het gedrag van werkgever en werknemer op elkaar te betrekken en een definitie van goed werkgeverschap en goed werknemerschap te formuleren.

Trefwoorden: goed werkgeverschap, goed werknemerschap, arbeidsrelatie

\section{Inleiding}

Tot nu toe domineert de juridische invalshoek in de discussie over goed werkgeverschap. Werkgevers en werknemers moeten zich volgens de wet als een goed werkgever en goed werknemer gedragen (boek 7:611 BW). Wat dat precies is, wordt niet omschreven. Het gaat hier om wat De Wit (1999) omschrijft als een 'vage norm'. De rechter oordeelt op basis van begrippen als 'redelijkheid en billijkheid' in situaties waarin een conflict is ontstaan. De Wit tracht in haar proefschrift te komen tot een nadere invulling van deze 'vage norm'. Dat doet ze onder meer door de grenzen van redelijkheid, billijkheid en rechtszekerheid op te zoeken.
Haar conclusie luidt dat deze begrippen nooit zullen samenvallen. Ze zijn als afzonderlijke begrippen onmisbaar in een rechtvaardig rechtssysteem.

De laatste decennia is de gepubliceerde jurisprudentie over de norm van goed werkgeverschap gegroeid. Bij gebrek aan scherpe, wettelijke normen neemt de rechter immers beslissingen om knelpunten op te lossen. Teurlings (2002) geeft aan dat de rechter dit doet met 'redelijkheid en billijkheid'. Deze termen worden vaak samen of afwisselend met de term 'goed werkgeverschap' gebruikt en hebben dezelfde betekenis. Wat is redelijkheid en billijkheid? Het antwoord is: dat wat in het maatschappelijke verkeer aanvaardbaar wordt geacht:

\footnotetext{
* De auteurs zijn werkzaam bij TNO Kwaliteit van Leven I Arbeid. E-mail: r.huiskamp@arbeid.tno.nl.
} 
"Een algemeen gevoel dat iets hoort, rekening houdend met algemeen erkende rechtsbeginselen zoals respect voor anderen, het waarborgen van de menselijke vrijheid".

Over goed werknemerschap is veel minder jurisprudentie, maar het tij lijkt te keren. Het krijgt de laatste tijd meer aandacht in de rechtspraak. Naar onze mening heeft dit te maken met het gegeven dat zelfstandigheid en eigen verantwoordelijkheid in de samenleving op diverse plaatsen verankerd raken (zie bijvoorbeeld de wijzigingen in de sociale zekerheid en in de zorgverzekeringen) en nu ook in arbeidsrelaties een vaste plek krijgen. Ook voor de rechterlijke macht is eenzijdige zorg van de werkgever voor de werknemer verleden tijd.

Tot de onderwerpen die onder goed werknemerschap vallen, noemt Heerma van Voss (1999) onder meer schending van de geheimhoudingsplicht en gebrek aan loyaliteit van de werknemer. Voorts wordt hierbij genoemd: medewerking aan een wijziging van de arbeidsovereenkomst, bereid zijn tot overleg over een andere functie en meer algemeen ingaan op redelijke voorstellen van de werkgever.

Goed werkgeverschap en goed werknemerschap (zij het in mindere mate) zijn termen die tot voor kort voornamelijk in de juridische context werden gebruikt. De omschrijving in het Burgerlijk Wetboek is algemeen van aard, en ondanks concretisering in de loop der tijd door jurisprudentie is de omschrijving slechts in zeer beperkte mate geschikt om als uitgangspunt te dienen voor gedragswetenschappelijk onderzoek.

Een van de thema's in het kennisinvesteringsprogramma in het kader van de aan TNO toegewezen overheidsfinanciering van het ministerie van Sociale Zaken en Werkgelegenheid betreft sociaal ondernemingsbeleid. Dit thema heeft als focus 'Goed werkgeverschap en Goed werknemerschap'. Het programma bestaat uit verschillende projecten en heeft inmiddels geleid tot een aantal resultaten en publicaties. De doelstelling is tweeledig. In de eerste plaats theoretisch: het empirisch toetsbaar maken van de begrippen met het oog op nader onderzoek. In de tweede plaats praktisch: denk aan het ontwikkelen van een 'microfundering van het poldermodel' door het stimuleren van 'volwassen' arbeidsverhoudingen in de bedrijven en instellingen, in het bijzonder in het overleg tussen medewerker en direct leidinggevende. In deze bijdrage richten wij ons op de theoretische doelstelling.

In het programma wordt niet alleen gekeken naar de ontwikkelingen op macroniveau (bijvoorbeeld de groei van de kenniseconomie, krapte op de arbeidsmarkt), maar met name naar de betekenis van goed werkgeverschap en goed werknemerschap binnen ondernemingen en instellingen. Hoe gaan ze om met goed werkgeverschap en goed werknemerschap? Hoe zullen goed werkgeverschap en goed werknemerschap zich in de toekomst verder ontwikkelen?

Voor een eerste terreinverkenning (Goudswaard et al., 2004) zijn gesprekken gevoerd met onder meer managers van bedrijven en instellingen die zich op het terrein van werkgeverschap in positieve zin hebben onderscheiden. Daaronder bevinden zich prijswinnaars van 'Great place to Work', 'Beste Baas', 'Beste ondernemer', 'Kroon op het werk', enzovoort. Er blijkt geen eenduidige omschrijving te bestaan van goed werkgeverschap. Sommige antwoorden zijn een reactie op het woord 'goed' in goed werkgeverschap. Er wordt uiting gegeven aan een positief mensbeeld en werkklimaat.

\section{Box 1 Reacties op de term 'goed'}

Termen die gebruikt worden zijn bijvoorbeeld:

- mensen serieus nemen en vertrouwen;

- luisteren en weten wat er speelt;

- respect voor het individu;

- een betrouwbare, veilige en voorspelbare omgeving;

- open communicatie en inspraak van personeel;

- transparantie.

Andere antwoorden sluiten meer aan bij het woord 'werkgeverschap'. Hierbij staat de (individuele) (arbeids)relatie tussen werkgever en werknemer centraal. 


\section{Box 2 Reacties op de term 'werkgever- schap'}

Termen die gebruikt worden zijn bijvoorbeeld:

- continuïteit van de organisatie en werkgelegenheid;

- een goede ruil tussen werkgever en werknemer;

- een dialoog van volwassen gesprekspartners;

- het bieden van concurrerende arbeidsvoorwaarden.

Een laatste invalshoek die naar voren komt als spontane reactie op het begrip goed werkgeverschap, heeft te maken met de plaats van de organisatie in de maatschappij. Om invulling te geven aan het begrip goed werkgeverschap vinden respondenten het essentieel na te denken over en aan te sluiten bij de missie van de organisatie tot uitdrukking komend in bijvoorbeeld verantwoordelijkheid jegens klanten, aandeelhouders en maatschappij.

Opmerkelijk is dat wetgeving en stimulansen vanuit de overheid geen rol van betekenis spelen bij goed werkgeverschap. Diverse respondenten vinden zelfs dat wetgeving de noodzakelijke dialoog tussen werkgever en werknemers eerder verstoort dan stimuleert. Ze leggen de primaire verantwoordelijkheid voor goed werkgeverschap bij de bedrijven zelf, in de relatie tussen werkgever en werknemer en (eventueel) bij sociale partners, maar niet bij de overheid.

Managers vragen naar goed werknemerschap levert een lange lijst met verwachtingen op. In de eerste plaats verwachten managers dat werknemers primair handelen vanuit het belang van de organisatie en hun gedrag in de context van organisatiedoelen plaatsen (opereren uit naam van organisatie, bereidheid vanuit werkgeversperspectief te denken, het geheel gaat voor het individu). In de tweede plaats verwachten ze dat werknemers zich professioneel gedragen (integer, technisch vaardig, klantgericht) en bereid zijn zich verder te ontwikkelen. In het verlengde hiervan verwachten managers van werknemers dat ze communicatief zijn, loyaal en goede teamspelers (een open mentaliteit, samenwerken aan een betere werksfeer, elkaar durven aanspreken op ongewenst gedrag). Opvallend zijn de verwachtingen over de verantwoordelijkheid van de werknemer in het werk en in de arbeidsrelatie. De werknemer moet zelf actie ondernemen om zijn talenten te ontwikkelen en ondernemerschap tonen. Hij moet tevens kritisch zijn ten opzichte van het management en doorvragen als dat nodig is. Hij moet opkomen voor zijn rechten, maar wel binnen grenzen van redelijkheid en billijkheid, dus niet vragen wat niet haalbaar is, vooral op het vlak van arbeidsvoorwaarden.

Uit de eerste verkenning blijkt dat een groot aantal omschrijvingen van goed werkgeverschap en goed werknemerschap in de praktijk in omloop zijn. Omschrijvingen waarachter vaak een normatieve visie op de mens en de arbeidsrelatie schuilgaat. We gaan in dit artikel daarom eerst met een open vizier de drie wetenschappelijke disciplines van economie, psychologie en sociologie doorzoeken op hun bijdrage aan de studie van goed werkgeverschap en goed werknemerschap en vragen ons af of ook daar normatieve visies op mens en arbeidsrelaties meespelen. Vervolgens wordt een conceptueel model voor goed werkgeverschap (GWS) en voor goed werknemerschap (GWN) gepresenteerd. Met dit model proberen wij de begrippen empirisch toetsbaar te maken met het oog op nader onderzoek.

\section{Drie wetenschappelijke disciplines doorzocht}

\section{Economie}

In de economie besteden we aandacht aan twee theorieën: de agency-theorie en de human capital-theorie. De agency-theorie geeft inzicht in de relatie goed werkgeverschap/goed werknemerschap als principaal en agent. De human capital-theorie biedt gelegenheid het investeringsgedrag van de werkgever in de opleiding en vaardigheden van de werknemer te voorspellen.

In de agency-theorie (Jensen \& Meckling, 1976) wordt onderscheid gemaakt tussen de agent (voert activiteiten uit ten behoeve van de ander in ruil voor beloning) en de principaal (de persoon voor wie de agent de opdracht uitvoert). Voorbeelden zijn eigenaars en leiding van een onderneming (aandeelhouders en directie), overheid en belastingbetaler, 
kredietgever en kredietnemer en zo ook werkgever en werknemer. Tussen de agent en de principaal komt een contract tot stand, waarvan de inhoud en de beloning samenhangen met de mate waarin partijen risico-avers zijn en de mate van informatie(a)symmetrie tussen beiden.

Indien de agent (= werknemer) risico-avers (afkerig) is, wordt er een vaste beloning afgesproken. Het is de principaal (= werkgever) die de risico's loopt ten aanzien van de opbrengsten. Extra inspanningen van de werknemer komen niet hemzelf ten goede, maar de werkgever. Als de werknemer risicoavers is, is er sprake van een 'first best'contract. In andere gevallen ontstaat een 'second best'-contract. In het bijzonder is dit van toepassing als er sprake is van informatieasymmetrie: de activiteiten van de agent kunnen door de principaal niet zelf worden gezien en beoordeeld. Twee verschijnselen spelen daarbij een rol:

1 Een werknemer maakt zijn handelen niet (volledig) openbaar en de werkgever is niet volledig geïnformeerd. De werkgever kan dus geen onderscheid maken tussen de verschillende factoren die van invloed zijn op de resultaten (hidden information; ex ante).

2 De werkgever kan, nadat de resultaten geleverd zijn, niet nagaan wat aan de inspanningen van de werknemer is toe te schrijven en wat niet (hidden action; ex post).

Op de achtergrond speelt de cruciale vraag van de beheersing van opportunistisch gedrag van agent en principaal, waarbij verborgen agenda's en handelingen vooral worden toegedicht aan de agent, de werknemer.

Goed werkgeverschap en goed werknemerschap kunnen vanuit de agency-theorie geduid worden als de mate waarin sprake is van het 'first best' contract, hetgeen impliceert dat bij beiden verborgen agenda's en opportunisme tot een minimum zijn teruggebracht.

In de human capital-theorie wordt inzicht geboden in het waarom van investeringen van de werkgever in de competenties van de werknemer. Lepak en Snell (2002) stellen dat diverse economische theorieën, maar in het bijzonder de human capital-theorie, tot de conclusie komen dat de investeringen van de werkgever in de competenties van de werknemer afhangen van de waarde en de uniciteit van die competenties voor de organisatie. De waarde betreft de mate waarin de competenties van de werknemer de efficiency en de effectiviteit van de organisatie vergroten. Het zijn competenties die van groot belang zijn om een bestaande marktpositie van de organisatie te benutten. De uniekheid van competenties betreft de mate waarin de competenties van de werknemer zeldzaam zijn en niet eenvoudig te repliceren door concurrenten. Ze zijn in hoge mate bepalend voor het verkrijgen van een voorsprong op de markt. De veronderstelling is nu dat de mate waarin de werkgever investeert in opleidingen en competenties van werknemers selectief is, namelijk samenhangt met de waarde en uniciteit van de competenties van de werknemer.

Goed werkgeverschap in de human capitaltheorie kan benaderd worden vanuit de mate waarin de werkgever investeert in de competentieontwikkeling van de werknemers.

\section{Psychologie}

In de psychologie ligt het voor de hand terug te grijpen op klassieke theorieën over motivatie en betrokkenheid. Simpel gezegd: een goede werknemer is een gemotiveerde en betrokken werknemer, maar daarmee is weinig gezegd over de werkgever. In dit onderdeel concentreren we ons daarom op twee meer recente loten aan de stam: theorievorming over het psychologische contract en over 'organisational citizenship behaviour'.

In de psychologie is de laatste tijd veel aandacht voor het psychologische contract. In het formele arbeidscontract wordt maar een deel van de rechten en verplichtingen over bijvoorbeeld het loon en de werktijden neergelegd. De vele verwachtingen die niet in het formele, expliciete contract staan, vormen het impliciete, psychologische contract tussen werkgever en werknemer.

In de eerste benaderingen, in de jaren zeventig en tachtig van de vorige eeuw, wordt het psychologische contract gezien als een ongeschreven overeenkomst tussen de organisatie en de individuele werknemer. Schein (1980) definieert het psychologische contract als 'an unwritten set of expectations operating at all times between every member of an organiza- 
tion and the various managers and others in the organization'. Deze auteur legt de nadruk op het psychologische contract als een middel om de 'exchange relationship' tussen werkgever en werknemer te beschrijven en te verklaren. De aandacht gaat vooral uit naar de processen van wederkerigheid en ruil in het proces van contractvorming.

In de jaren negentig wordt deze ruime procesgerichte opvatting van het psychologische contract verlaten en vervangen door een ander concept. Proponent van deze ontwikkeling is bij uitstek Rousseau. Rousseau (1995) en Robinson, Kraatz \& Rousseau (1994) gaan uit van een intra-individuele definitie van het psychologische contract. Het psychologische contract is een impliciet contract dat alleen in het hoofd van een medewerker bestaat. Er bestaat dan ook geen overeenstemming met (leidinggevenden van) de organisatie, want het heeft alleen betrekking op de perceptie van de medewerkers van hun relatie met de organisatie (Ten Brink \& Van Muijen, 2000). De inhoud van het psychologische contract omvat aldus de opvattingen van de medewerker over wat hij aan de organisatie verplicht is en wat de organisatie aan hem verplicht is. De mate van vervulling van het psychologische contract omvat de mate waarin de medewerker meent dat de organisatie voldoet aan de verplichtingen ten opzichte van hem. Daarmee is de vervulling van het psychologische contract beperkt tot de verplichtingen van de organisatie. Ook wordt onderzoek verricht naar 'breach of psychological' contract ofwel naar de mate waarin de organisatie contractbreuk pleegt ten opzichte van de oorspronkelijke impliciete verwachtingen, bijvoorbeeld bij indiensttreding. In het psychologische contract wordt daarnaast vaak een onderscheid gemaakt tussen het transactionele deel en het relationele deel. Het transactionele deel slaat op de zakelijke kant van het contract, op de economische ruil, het relationele deel heeft betrekking op de sociale kant. Goed werkgeverschap kan bestudeerd worden als de mate waarin de werknemer meent dat de werkgever zijn verplichtingen nakomt. Het is jammer dat de afgelopen jaren de brede opvatting van het psychologische contract als een ruilproces tussen werkgever en werknemer verlaten is voor het psychologische contract als een mentaal beeld van de werk- nemer. Als dat niet het geval zou zijn, zou het psychologische contract ook een ingang bieden om goed werknemerschap te onderzoeken als de mate waarin de werkgever meent dat de werknemer aan zijn verplichtingen voldoet.

In het verlengde van het psychologische contract stelt Herriot (2001) dat in arbeidsrelaties dezelfde psychologische factoren spelen als in alle andere relaties tussen mensen. Personen hebben een zelfbeeld, gevormd in en door interactie met anderen. Het zelfbeeld bevat elementen zoals identiteit, zelfwaardering en reflexiviteit. Het is opgebouwd uit ervaringen van relaties met anderen en is van invloed op bestaande relaties, de arbeidsrelatie vormt hier geen uitzondering op.

Vanuit psychologisch perspectief heeft Herriot acht metaforen voor arbeidsrelaties geformuleerd. Elke metafoor heeft een positieve kant en een negatieve kant, een 'flipside': het beeld slaat ineens om van positief naar negatief. Wanneer de negatieve kant van de metafoor domineert, is er iets grondig mis met de arbeidsrelatie. Het zelfbeeld van de werknemer wordt geschaad.

We noemen enkele voorbeelden. Denk aan een werkgever die arbeidsrelaties vormgeeft op basis van een familiemetafoor: geborgenheid en zorg en steun zijn de positieve kanten daarvan. De negatieve kant is overbezorgdheid, misbruik maken en het gevaar bij iedere familie: een familievete. Een ander voorbeeld is een werkgever die de organisatie modelleert op een contractuele gemeenschap. De positieve kant zijn de duidelijke rechten en plichten, de negatieve kant vormt contractbreuk, tot het uiterste je rechten opeisen en uiteindelijk in een jungle belanden waar het recht van de sterkste geldt.

In tabel 1 zijn de acht metaforen weergegeven.

Wanneer doen 'flipsides' zich voor? Als het topmanagement zichzelf en anderen een rad voor ogen draait door met retoriek de neuzen in dezelfde richting te krijgen. Retoriek is gericht op het beïnvloeden van andermans overtuigingen en gevoelens, zonder rekening te houden met het zelfbeeld. Het gaat voorbij aan psychologische principes van relaties tus- 
Goed werkgeverschap en goed werknemerschap

Tabel 1 Metaforen van arbeidsrelaties (bewerking naar Herriot, 2001)

\begin{tabular}{|lll|}
\hline & Positieve kant metafoor & Negatieve kant metafoor \\
\hline Familie & veiligheid, zorg en steun & overbezorgdheid, misbruik, vete \\
Kruistocht & missie, charisma & cynisme, narcisme \\
Contractuele gemeenschap & rechten en plichten & contractbreuk, verhaalhalen, jungle \\
Club & inzet, erbij horen & uitsluiting, groupthink, exclusiviteit \\
'Resource' & waardevolle bron, & \\
& toegevoegde waarde & schijninspraak, belangen verhullen \\
Democratie & inspraak, legitimatie & belangenconflict \\
Partnerschap & mede-eigenaar, & \\
& gezamenlijke belangen & valse reclame, afzetterij \\
Klant & service & \\
\hline
\end{tabular}

sen personen en dus die van arbeidsrelaties. Negatieve percepties van de arbeidsrelaties zijn het gevolg. Het contrast van retoriek is de dialoog, waarin de gevoelens van de ander en de eigen gevoelens verhelderd worden en waarbij de zelfconcepten van partijen worden onderkend. Goed werkgeverschap komt tot uitdrukking in het aangaan van een werkelijke dialoog met de werknemer, goed werknemerschap betekent openstaan voor deze dialoog.

Organizational citizenship behaviour (OCB) is voortgekomen uit onderzoek naar in- en extrarole behaviour. In-role gedrag kan omschreven worden als het vereiste en verwachte gedrag en is de basis van wat de werknemer behoort te presteren in het werk. Ofwel doen waarvoor je betaald wordt (Katz, 1964). Als werknemers niet doen waarvoor ze betaald worden, krijgen ze geen extra beloning en riskeren ze zelfs ontslag. Extra-role gedrag: dit gedrag kun je omschrijven als extra positieve dingen doen in je werk waarvoor je niet betaald wordt. Het valt uiteen in vier typen gedrag (VanDyne \& LePine, 1998):

1 promotioneel gedrag: proactief gedrag dat gericht is op aanmoedigen en helpen;

2 beschermend gedrag: opkomen voor collega's met minder macht en je uitspreken over ethisch onaanvaardbaar gedrag;

3 coöperatief gedrag: interpersoonlijk en relatieversterkend gedrag gericht op collega's;

4 creatief/uitdagend gedrag: gericht op het creëren van nieuwe ideeën en het veranderen van werksituaties.
OCB is een verzamelnaam voor alle soorten niet-voorgeschreven individueel gedrag dat gunstig is voor de organisatie (Bateman \& Organ, 1983). OCB is individueel, vrijwillig gedrag. Het wordt veelal niet expliciet erkend in het formele beloningssysteem, maar draagt niettemin wel bij aan de prestaties van de organisatie. OCB is essentieel, omdat organisaties niet kunnen anticiperen op het geheel aan benodigde gedragingen louter op basis van alle formele in-role functieomschrijvingen (George \& Brief, 1992). OCB kent vijf dimensies:

- altruïsme: vormen van OCB waarbij medewerkers elkaar helpen;

- conscientiousness of generalized compliance: gedrag waarbij medewerkers meer doen dan de norm teneinde de organisatie als geheel beter te laten presteren;

- courtesy: gebaren en acties gericht op het voorkomen van problemen van collega's;

- sportmanship: de bereidheid tot het verdragen en doorstaan van ongemakkelijke situaties zonder daarover te klagen;

- civic virtue: verantwoordelijke en constructieve betrokkenheid bij het organisatiebeleid.

Een belangrijke antecedent voor OCB is 'fairness', billijkheid. Verscheidene studies hebben aangetoond dat de perceptie van billijkheid in hoge mate wordt bepaald door de graad van participatie van medewerkers in de besluitvorming over hun werk (Porter, Lawler \& Hackman, 1996). De mogelijkheid van participatie van medewerkers in de besluitvorming van de organisatie vraagt van het management een zeker respect voor de rechten van 
de individuele werknemer. Het concept van billijkheid heeft ook een belangrijke plaats in het onderzoek naar rechtvaardigheid, uitgesplitst in 'procedural' en 'distributive justice'. Daarbij wordt niet alleen gekeken naar de procedure, de procedurele rechtvaardigheid, maar ook naar de verdeling van de uitkomst, de zogenaamde uitkomstrechtvaardigheid.

OCB biedt een goede ingang om goed werknemerschap te onderzoeken: in welke mate doen werknemers meer dan strikt vereist? Het concept van rechtvaardigheid biedt daarentegen een ingang om goed werkgeverschap te onderzoeken: in welke mate ervaart de werknemer de besluiten van de werkgever als rechtvaardig, zowel qua procedure als uitkomst.

\section{Sociologie}

In de sociologie is er minder sprake van uitgewerkte theorieën op basis van inductieve redeneringen over twee actoren (economie) of hypothesetoetsend onderzoek en het valideren van schalen (psychologie). Bovendien is een scherp onderscheid tussen sociologische inzichten en (sociale) psychologische niet eenvoudig te maken, bijvoorbeeld bij het concept van 'trust', vertrouwen.

In de sociologie is er veel aandacht voor het concept van vertrouwen. In de visie van Crouch (1994) bevatten alle sociale relaties een element van berekening en vertrouwen. Of het nu arbeid, vriendschap of zelfs liefde betreft. Hij ontwikkelt een continuüm van sociale relaties door een onderscheid te maken naar de mate waarin actoren elkaar kennen en de mate waarin de relatie gebaseerd is op (rationele) berekening.

- De eerste dimensie, de mate waarin actoren elkaar kennen, loopt - vrij vertaald - van onbekend en onbemind naar vertrouwd en bemind.

- De tweede dimensie, de mate waarin de relatie is gebaseerd op berekening, loopt van volledige berekening inclusief gedetailleerde specificatie van afspraken naar het ontbreken van zowel berekening als uitgebreide afspraken.

Crouch ziet de volgende samenhang tussen beide dimensies. Bij twee actoren die elkaar voor het eerst leren kennen, zal de relatie in sterke mate gebaseerd zijn op berekening en uitgebreide specificatie. Door herhaalde interactie ontstaat er een wederzijds belang in de relatie. Als het aantal interacties toeneemt, is het niet nodig iedere ruil opnieuw te calculeren en te specificeren. Er ontstaat vertrouwen. Naarmate de actoren elkaar beter leren kennen vermindert de behoefte aan calculatie en contractvorming. Crouch ontwikkelt zo een continuüm van relaties gebaseerd op formele specificaties en berekening, gedeelde normen en op vriendschap.

In omschrijvingen van vertrouwen wordt nadrukkelijk afstand genomen van een instrumentele opvatting van vertrouwen |= economisch) en wordt een relationele omschrijving naar voren geschoven. Bijvoorbeeld:

"Trust is one party's willingness to be vulnerable to another party based on the belief that the latter party is a) competent, b) open, c) concerned and d) reliable"

(Mishra, 1996).

Ook worden termen genoemd als respect, waardigheid en gelijke behandeling. Een andere omschrijving is:

"Trust refers to the beliefs that other people maintain about the other party's future behaviour" (Brockner \& Siegel, 1996).

Dietz (2004) maakt een onderscheid tussen vertrouwen gebaseerd op berekening en vertrouwen gebaseerd op identificatie met de ander. In het onderzoek naar billijkheid is ook veel aandacht voor het interactie-effect tussen procedurele en uitkomstrechtvaardigheid, waarbij het begrip vertrouwen een belangrijke rol speelt. Procedurele rechtvaardigheid wordt dan gezien als een antecedent voor vertrouwen en vertrouwen speelt weer een grote rol in het beoordelen van de uitkomst door het individu.

Goed werkgeverschap en goed werknemerschap zouden we dus kunnen omschrijven als een arbeidsrelatie gebaseerd op vertrouwen. Een belangrijk onderdeel van vertrouwen is het beheersen van het eigen belang. Mühlau (2000) voert aan dat het streven naar eigen voordeel alleen mogelijk is, als het ingeka- 
derd wordt in gedeelde sociale normen en verwachtingen. Een sociale relatie waarin beide partijen hun eigen voordeel nastreven, kan alleen floreren als partijen hun eigen belang beheersen; alleen zo kan de goede wil van de andere partij behouden blijven. Akerlof (1982) wijst erop, aansluitend bij antropologische theorieën, dat het gedrag tussen werknemers en werkgevers omschreven kan worden als een zogenaamde 'giftrelatie'. Van de kant van de werknemers bestaat de gift uit arbeid die verricht wordt boven de minimumvereisten (bijvoorbeeld onbetaald overwerk). Van de kant van de organisatie bestaat de gift uit de lonen die hoger liggen dan elders op de markt. Dit is nergens tussen werkgever en werknemer vastgelegd, het is gebaseerd op gedragsnormen die deel uitmaken van het impliciete contract. Goed werkgeverschap en goed werknemerschap kunnen vanuit deze visie als een giftrelatie beschouwd worden, die bijvoorbeeld tot uiting komt in onbetaald overwerk en een hoger loon dan gebruikelijk op de markt.

Comer (1995) zet ons met het begrip 'social loafing', klaplopen ofwel zich drukken, weer met beide benen op de grond. Comer definieert klaplopen als de afname van de inspanning van leden van een groep. Een belangrijke factor die deze afname verklaart, is het gebrek aan de waargenomen individuele bijdrage en het ontbreken aan externe evaluatie daarop. Zodra individuen beseffen dat hun individuele bijdrage niet traceerbaar is voor de werkgever of collega's verlagen zij hun inspanning, vooral als zij weinig gemotiveerd zijn om te presteren en het risico dat profiteren leidt tot onenigheid met collega's laag inschatten.

Andere factoren die bepalend zijn voor het ontstaan van klaplopen zijn:

- vermijden van de sucker rol (degene van wie misbruik wordt gemaakt). Deze wens is groter naarmate werknemers zien dat enkele collega's hun inspanning verlagen;

- gebrek aan invloed op de einduitkomsten van een taak en de overtuiging dat jouw bijdrage niet bepalend is voor het eindresultaat;

- vermijden dat anderen je te competent of te incompetent vinden.

Voor goed werknemerschap betekent dit dat er groepsprocessen zijn die werknemers ervan weerhouden hun best te doen en maximaal uitvoering te geven aan hun functie.

\section{Normatieve visies in de wetenschap}

De zoektocht door de disciplines levert een lijst van wetenschappelijke concepten op die bruikbaar zijn in het onderzoeken van goed werkgeverschap en goed werknemerschap. We concluderen dat:

- een aantal concepten in meer benaderingen voorkomt. Bijvoorbeeld vertrouwen in zowel de economische, sociologische als psychologische benadering. Andere begrippen zijn benaderingspecifiek, zoals een 'first best' - en 'second best'-contract;

- sommige concepten weliswaar in meer benaderingen terugkomen, maar in een andere uitwerking en plaats in de theorie. Zo is vertrouwen in sociologische modellen een afhankelijke variabele, maar in de OCBtheorie (psychologie) een antecedent;

- sommige concepten alleen op werkgeversgedrag toepasbaar zijn en andere alleen op werknemersgedrag. Zo wordt met het psychologische contract het gedrag van de werkgever (nakomen van verplichtingen) bij de werknemer onderzocht. OCB is daarentegen geheel gericht op het in beeld brengen van het gedrag van de werknemer.

Hoe kunnen we nu vanuit wetenschappelijke theorievorming de stap zetten naar een normatief concept als GWS en GWN? Het bijvoeglijke naamwoord 'goed' benadrukt het normatieve, evenals de toevoeging 'schap'. Denk bijvoorbeeld aan 'schap' in zo langzamerhand ouderwetse klinkende woorden als rentmeesterschap of nabuurschap. Dat duidt op zorgen voor een zaak of de ander, je verantwoordelijk voelen. Doemt hier een fundamenteel methodologisch probleem op? Is het mogelijk op basis van 'positieve' wetenschappelijke theorieën die open willen staan voor empirische toetsing en falsificatie een wetenschappelijke modellering van normatieve begrippen als GWS en GWN te maken? De Vries (1995) meent dat het een illusie is dat de wetenschap zich op de feiten richt en de politiek op normatieve noties. Sociologisch en filosofisch onderzoek naar de praktijk van wetenschap en onderzoek toont aan dat 
'wetenschap in actie' een mengsel is van wetenschap en politiek. Paauwe (2004) bepleit zelfs een ethisch HRM als tegenvoeter van een waardevrije beoefening van de personeelswetenschappen, het is het centrale thema van zijn boek. In zijn ogen produceert de onderneming niet alleen winst, economische waarde, maar ook morele waarde(n).

De visie van De Vries wordt ondersteund als we de door ons behandelde theorieën uit de economie, psychologie en sociologie nog eens de revue laten passeren. We stuiten in die theorieën telkens op een tweedeling in de normatieve visie op de mens en de arbeidsrelatie. De tweedeling uit zich in verschillende vooronderstellingen over de intentie tot gedrag van een actor:

- De ene visie veronderstelt dat opportunisme hoogtij viert, vooral onder werknemers /vandaar de noodzaak tot uitgebreide systemen van controle en toezicht in de organisatie). De actoren zijn uit op het maximaliseren van het eigenbelang en ze houden informatie achter. De mens is een calculerende actor. Als er vertrouwen is tussen de twee actoren, is dit hoogstens gebaseerd op calculatie, op berekening. De arbeidsrelatie is een puur zakelijke relatie, voor wat hoort wat en 'misschien kan ik er een slaatje uit slaan'.

- In de andere visie doemt een geheel ander beeld op. In de veronderstellingen over de intentie tot gedrag worden het zich inleven en identificeren met de ander en het beheersen van het eigen belang benadrukt. De mens is een altruïstische actor. Vertrouwen is het cement van de relatie, een gevoelsmatige vorm van vertrouwen. De arbeidsrelatie is een giftrelatie, de een geeft meer dan strikt noodzakelijk en dit gebaar wordt geretourneerd door de ander.

In tabel 2 zijn de behandelde concepten gerangschikt naar deze twee normatieve visies.

In de visie van de calculerende mens en de zakelijke relatie is er sprake van een 'second best'-contract tussen werkgever en werknemer met ongelijkwaardige informatie, de werkgever investeert selectief in opleidingen en het vertrouwen is calculerend van aard. De verplichtingen van werkgever en werknemer zijn vooral zakelijk van aard en de kans bestaat op klaplopen, het zich drukken. De communicatie tussen werkgever en werknemer en de besluitvorming is eenzijdig en doordrenkt van retoriek.

In de visie van de altruïstische mens en een relationele giftrelatie is er sprake van een 'first best'-contract met gelijkwaardige informatie: de werkgever investeert breed in opleidingen, de betrokkenheid heeft een affectieve basis en het vertrouwen is relationeel. De verplichtin-

Tabel 2 Normatieve visie en concepten voor studie GWS en GWN

\begin{tabular}{|c|c|c|}
\hline $\begin{array}{l}\text { Normatieve visie op } \\
\text { mens en arbeidsrelatie }\end{array}$ & $\begin{array}{l}\text { Veronderstellingen intentie } \\
\text { tot gedrag werkgever en } \\
\text { werknemer }\end{array}$ & $\begin{array}{l}\text { Wetenschappelijke concepten } \\
\text { voor studie GWS en GWN }\end{array}$ \\
\hline $\begin{array}{l}\text { - calculerende mens } \\
\text { - zakelijke relatie }\end{array}$ & $\begin{array}{l}\text { - opportunisme } \\
\text { - maximaliseren eigen belang } \\
\text { - berekening } \\
\text { - retoriek }\end{array}$ & $\begin{array}{l}\text { - second best contract } \\
\text { - selectief investeren in opleidingen } \\
\text { - transactioneel deelpsychologisch contract } \\
\text { - calculerend vertrouwen } \\
\text { - social loafing } \\
\text { - top-down besluitvorming }\end{array}$ \\
\hline $\begin{array}{l}\text { - altruïstische mens } \\
\text { - relationele giftrelatie }\end{array}$ & $\begin{array}{l}\text { - identificatie/inleving } \\
\text { - beheersen eigen belang } \\
\text { - onbaatzuchtig } \\
\text { - dialoog }\end{array}$ & $\begin{array}{l}\text { - first best contract } \\
\text { - breed investeren in opleidingen } \\
\text { - relationeel deel psychologisch contract } \\
\text { - relationeel vertrouwen } \\
\text { - OCB } \\
\text { - participatieve besluitvorming }\end{array}$ \\
\hline
\end{tabular}


gen van werkgever en werknemer zijn primair relationeel en de kans bestaat op méér doen dan strikt gezien noodzakelijk is (extra-role gedrag, ofwel OCB). De communicatie tussen werkgever en werknemer en de besluitvorming zijn tweezijdig en gebaseerd op dialoog. Sommige begrippen zijn zelfs bipolair. Denk aan een calculerende en een relationele opvatting van vertrouwen en een transactioneel en relationeel psychologisch contract. Zo wordt in een onderzoeksinstrument, in een schaal, de normatieve lading verwerkt.

\section{Het model GWS en GWN}

In een tweede stap is een model voor GWS en GWN ontwikkeld. Dit model moet voor het onderzoek het volgende opleveren:

- het gedrag van werkgever en werknemer op elkaar betrekken;

- een onderscheid tussen onafhankelijke, modererende en afhankelijke variabelen;

- een selectie van concepten uit de literatuur;

- een definitie van GWS en GWN.

Het startpunt van het model is (het niveau van) de arbeidsrelatie tussen een werkgever en een werknemer. Het begrip arbeidsrelatie als analyseobject van personeelswetenschappen is op verschillende plekken en eerdere tijdstippen al gedefinieerd en uitgewerkt, bijvoorbeeld door Kluytmans (1999) en Huiskamp (2003), mede gebaseerd op het werk van psychologen zoals Schein (1980) en Rousseau (1995). Zij leggen in hun omschrijving de nadruk op de arbeidsrelatie als ruilrelatie. Binnen organisaties gaan werknemers en werkgevers onderling een relatie aan, met als oogmerk een (deel van) product of dienst voort te brengen. De werknemer stelt zijn arbeidsvermogen ter beschikking aan de werkgever, levert een prestatie en de werkgever stelt daar een beloning (in ruime zin) tegenover. Wederzijdse verwachtingen van economische, persoonlijke of sociale aard, impliciet of expliciet, sturen het gedrag van actoren in ruil.

We sluiten ons vervolgens aan bij de expectancy-value theorie zoals ontwikkeld door Fishbein en Ajzen (1975) en later door velen verder uitgewerkt en toegepast in het voorspellen van gedrag bij interventieprogramma's (bijvoorbeeld voor roken, gewichtsvermindering of gezinsplanning, bij stemgedrag in verkiezingen of referenda of bij verzuim en verloop). Een recente toepassing in Nederland (Langedijk, 1998) is het voorspellen van keuzegedrag in à la carte-systemen. De hoofdgedachte van deze theorie is dat de intentie tot gedrag een belangrijke determinant is van het feitelijke gedrag. De intentie tot gedrag wordt daarbij niet alleen beïnvloed door het persoonlijke oordeel van de actor dat zijn of haar gedrag leidt tot de gewenste uitkomsten, maar vooral door de verwachtingen van de relevante ander(en). De veronderstelling is vervolgens dat de actor in zijn of haar gedrag meer rekening zal houden met de verwachtingen van de relevante ander(en) naarmate de ander(en) zelf de gevolgen van het gedrag ervaart en ondergaat. In elke arbeidsrelatie is dat tot op zekere hoogte het geval, maar in een arbeidsrelatie gebaseerd op goed werkgeverschap en goed werknemerschap in veel sterkere mate. Probeert de werknemer, rekening houdend met de verwachtingen van de werkgever, zo veel mogelijk geld te verdienen tegen de geringst mogelijke inspanning of is het zijn intentie zich volledig in te zetten voor de best mogelijk kwaliteit van het product of de dienst? Is het de intentie van de werkgever de werknemer precies omschreven werkopdrachten te geven opdat hij niet de kantjes ervan afloopt of verwacht de werkgever dat werknemers zich extra inzetten als ze verantwoordelijkheid in het werk hebben?

Aan het model zijn diverse verfijningen toegevoegd, maar voor ons volstaat op dit moment een eenvoudige versie van het gedragsmodel, bestaande uit drie componenten:

- de intentie tot gedrag;

- de verwachting van de relevante ander;

- het feitelijke gedrag.

In figuur 1 presenteren we de samenhang tussen deze drie componenten.

\section{Figuur 1 Gedragsmodel}

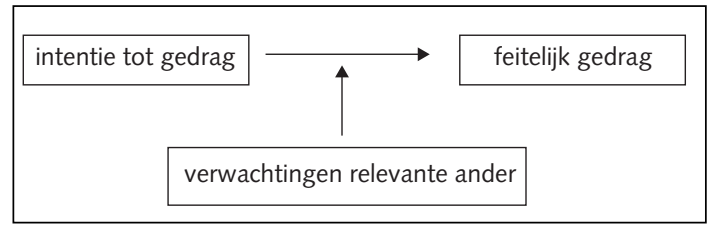




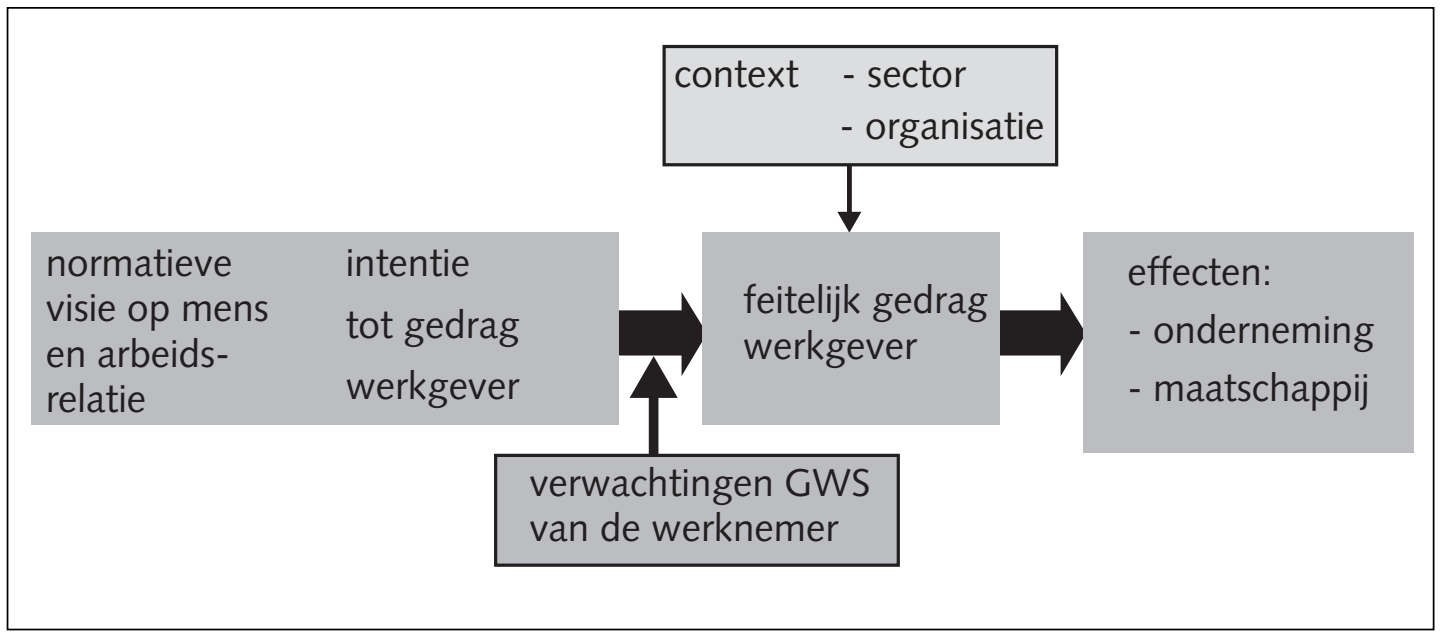

Figuur 2 Model goed werkgeverschap

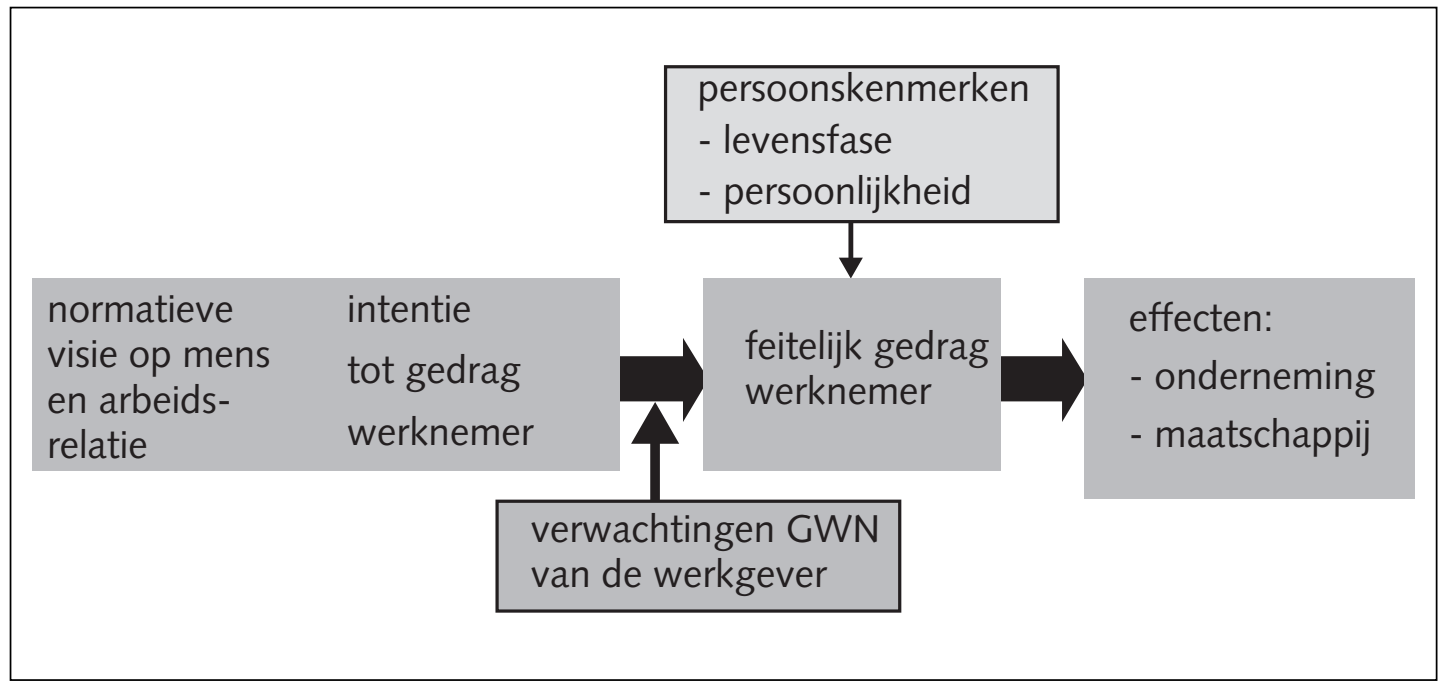

Figuur 3 Model goed werknemerschap

De modellen voor goed werkgeverschap en goed werknemerschap volgen de hoofdlijn van het gedragsmodel.

Het model GWS bevat de verwachtingen van de werknemer en omgekeerd bevat het model GWN de verwachtingen van de werkgever. Op deze wijze zijn goed werkgeverschap en goed werknemerschap modelmatig op elkaar betrokken. Aan de modellen voegen wij zoals gebruikelijk contextfactoren als modererende variabelen toe en uitkomsten als afhankelijke variabele.
We behandelen de modellen per hoofdgroep, per blok, van links naar rechts.

Eerst de normatieve visie op mens en arbeidsrelatie en de intentie tot gedrag. In onze behandeling van de wetenschappelijke theorievorming troffen we twee normatieve visies aan met daarmee samenhangende vooronderstellingen over de intentie tot gedrag. Bij het hanteren van deze twee visies ontstaat al snel de neiging de eerste benadering, de calculerende mens in een zakelijke relatie, als negatief te 
zien, als synoniem aan slecht werkgever- en werknemerschap. Omgekeerd is de neiging de tweede, de altruïstische mens in een giftrelatie, te zien als positief, als synoniem aan goed werkgever- en werknemerschap. Tot op zekere hoogte is dit juist, maar tot in het extreme doorgevoerd zou het leiden tot intenties die we alleen van een heilige kunnen verwachten en niet van een actor in een markteconomie. Een arbeidsrelatie zonder streven naar eigenbelang of geheel ontdaan van opportunisme is kunstmatig, evenals een relatie die geheel gebaseerd is op identificatie met de ander of op volledig vertrouwen.

Uit de sociologie halen wij de dimensie die loopt van calculerend vertrouwen, waarin alle afspraken worden genoteerd en gespecificeerd, tot relationeel vertrouwen, waarin specificatie en vastlegging overbodig is. Dietz (2004) maakt in zijn schaal onder meer onderscheid tussen vertrouwen gebaseerd op berekening en op gevoelsmatige identificatie met de ander. Dit onderscheid lijkt zeer bruikbaar als een van de maten voor de intentie tot gedrag.

Het tweede blok behelst de verwachtingen van de relevante ander als cruciale determinant van het feitelijke gedrag. Deze verwachtingen vormen een complex geheel, want de arbeidsrelatie is niet alleen een ruilrelatie, maar tegelijkertijd ook een gezagsrelatie en een samenwerkingsrelatie (Kluytmans, 1999). Op het moment dat de werknemer een arbeidscontract aangaat, onderwerpt hij zich aan het gezag van de werkgever lof aan de persoon van de gemandateerde leidinggevende) en is hij verplicht diens besluiten uit te voeren. De arbeidsrelatie kan bovendien alleen blijvend functioneren als er sprake is van samenwerking in de uitvoering van taken en er moet ruimte zijn voor feedback en overleg. Bolweg (1997) merkt op dat de werkgever graag de ruil en het gezag als 'scherpe kantjes van de arbeidsrelatie' verdoezelt en het over de boeg van de samenwerking probeert te gooien. De werkgever presenteert een beeld van spontaan met elkaar samenwerkende medewerkers. De samenwerkingsrelatie krijgt in het 'wijgevoel' een gevoelsmatige en zelfs paternalistische ondertoon. Kluytmans (1999: 238239) verwoordt het als volgt:
"Er is in de arbeidsrelatie sprake van het gelijktijdig werkzaam zijn van coöperatieve (samenwerking) en competitieve (ruil) tendensen en van hiërarchische (onderschikking) tendensen."

Zakelijk zijn, onderschikking accepteren en samenwerken; het vinden van de juiste balans tussen deze verwachtingen is geen vanzelfsprekend gegeven en een hele opgave. Bovendien is een arbeidsrelatie geen statisch gegeven, eens en voor altijd overeengekomen bij het aangaan van het arbeidscontract. Nee, de verhouding verandert juist voortdurend in de loop der tijd: de werkgever wil bijvoorbeeld op den duur meer en andersoortige prestaties /denk aan andere werktijden of een verschuiving in taken) en de werknemer wil zich verder kunnen ontplooien (bijvoorbeeld door het volgen van opleidingen). Deze verschuivingen leiden veelal niet tot een formele herziening van het arbeidscontract: ze leiden tot aanpassing van de wederzijdse impliciete en expliciete verwachtingen.

In feite zijn GWS en GWN een specifieke invulling van de arbeidsrelatie, een bijzonder geval in de zin dat de afstemming en wisselwerking tussen verwachtingen van de werkgever en de werknemer nog kritischer is dan in een gewone arbeidsrelatie. Het 'wij-gevoel' is niet voldoende. Actoren hebben hoge verwachtingen van elkaar en halfslachtig GWS en halfslachtig GWN volstaan niet. Oprechtheid in gedrag is van groot belang. Daarnaast kunnen goed werkgeverschap en goed werknemerschap niet als een soort windvaantje meewaaien met de resultaten van het bedrijf of de conjunctuur.

Wat voor een feitelijk gedrag (het derde blok) vertonen werkgever en werknemer? We benaderen dit vanuit de mate waarin dit gedrag totstandkomt in een dialoog. Een relevant onderdeel van de dialoog is volgens Oeij et al. (2005) de selectie van mogelijke arbeidsrelaties. Oeij et al. onderscheiden daartoe de arbeidsrelatie als een interpersoonlijke relatie en als een economisch-juridische relatie. Als interpersoonlijke relatie is er een continuüm van een secundaire naar een primaire relatie. Het duidt op een overgang van 'een betrekkelijk kortdurende relatie gekenmerkt door een beperkte sociale interactie, tamelijk duidelijk omschreven omgangsregels en tamelijk nauw omschreven sociale rollen' naar een 'basale, langdurige 
interpersoonlijke relatie gebaseerd op sterke emotionele banden en het gevoel van wederzijdse verplichtingen voor elkaar' (Clark \& Mills, 1979). Als economisch-juridische relatie is er een continuüm van een arbeidsrelatie naar een opdrachtrelatie. Doordat medewerkers meer op output gestuurd worden, meer op projectbasis werken en beloond worden naar prestatie verschuiven arbeidsrelaties in de richting van opdrachtrelaties. Tegenwoordig leggen werkgevers steeds meer nadruk op het nemen van risico en het vertonen van eigen initiatief door de werknemer. In feite sluipen kenmerken van een opdrachtrelatie in de arbeidsrelatie (Huiskamp \& Kluytmans, 2003). Beide dimensies zijn weergegeven in figuur 4. Wat voor een type arbeidsrelatie wil de werkgever in zijn onderneming en wat voor type interpersoonlijke relatie wil de werkgever als 'individu' met zijn of haar werknemers en omgekeerd? Om dit te verlevendigen hebben we de metaforen van Herriot in de kwadranten van de figuur geplaatst. Willen ze in een familieverband leven, een partnerschap vormen of een samen een kruistocht ondernemen?

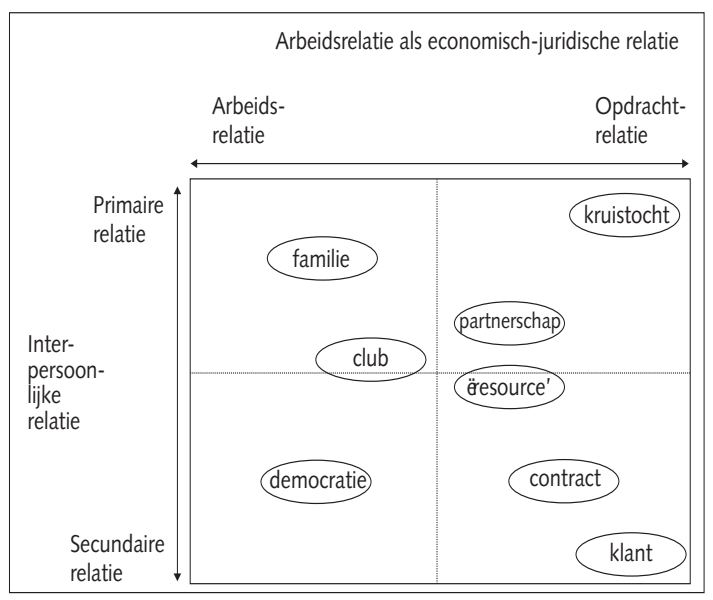

Figuur 4 Selectie van arbeidsrelaties

Bron: Oeij et al., 2005

Het selectieproces is niet neutraal in de zin dat de arbeidsrelatie een asymmetrische relatie is. De werkgever neemt bijvoorbeeld beslissingen over investeringen in de werknemer qua opleidingen of bepaalt in sterke mate de inhoud van het werk. Cruciaal is daarom de mate waarin het feitelijke gedrag totstandkomt in een dialoog, waarbij partijen zich verplaatsen in de positie van de ander, het is de kunst van het erkennen van de ander (Sennett, 2003).

We voegen aan de twee modellen een groep modererende variabelen toe, te weten contextfactoren (het vierde blok). Deze beïnvloeden zowel het feitelijke werkgevers- als werknemersgedrag rechtstreeks. Voor het werkgeversmodel denken wij aan de sector waarin de organisatie opereert en de omvang van de organisatie als contextvariabelen. De sector waarin een organisatie opereert, vertelt veel over de praktijk van het personeelsbeleid (Gründemann \& Van Dalen, 2002). De variabele grootteklasse is relevant, omdat kleine en middelgrote organisaties niet of bijna nooit beschikken over een eigen $\mathrm{P} \& \mathrm{O}$-afdeling. Hier is het personeelsbeleid sterk afhankelijk van de persoon van de directeur of eigenaar. Voor het werknemersmodel denken wij aan de levensfase en persoonlijkheid van de werknemer als modererende variabelen.

Ten slotte zijn we geïnteresseerd in de effecten van GWS en GWN op de organisatie en de samenleving (het vijfde blok). In de organisatie leven bij de werkgever verwachtingen over het effect van zijn gedrag op extra-role gedrag (OCB) van de werknemer, op onbetaald overwerk, het verzuim of het verloop; bij de werknemer over het effect van zijn gedrag op de hoogte van het loon, opleidingsmogelijkheden, voldoende hersteltijd enzovoort. In de samenleving leven verwachtingen over het gedrag van werkgevers en werknemers, denk bijvoorbeeld aan het bieden van kansen voor zwakke groepen op de arbeidsmarkt of discriminatie op het werk. Het gaat om effectmaten waarin de uitkomsten van het gedrag van werkgever en werknemer in de organisatie en de samenleving zichtbaar worden. Mogelijke maten voor de effecten zijn: verzuimpercentage, verlooppercentage, positie in een salaris-survey, type/budget opleidingen, onbetaald overwerk enzovoort.

Op basis van het model geven we de volgende definitie: GWS en GWN zijn gedragingen van werkgevers en werknemers waarin beiden optimaal rekening houden met de verwachtingen van de ander en in een dialoog de arbeidsrelatie vormgeven met het oog op de positieve uitkomsten voor de onderneming en de samenleving. 


\section{Conclusie}

De zoektocht door de disciplines van economie, psychologie en sociologie levert een lijst van wetenschappelijke concepten op die bruikbaar zijn in het onderzoeken van goed werkgeverschap en goed werknemerschap. De behandelde concepten zijn te rangschikken naar twee normatieve visies. De ene visie veronderstelt dat opportunisme hoogtij viert, vooral onder werknemers. Werkgevers en werknemers zijn uit op het maximaliseren van het eigenbelang en ze houden informatie achter. Ze zijn calculerende actoren in een puur zakelijke arbeidsrelatie. In de andere visie doemt een geheel andere beeld op. In de veronderstellingen over de intentie tot gedrag wordt het zich inleven en identificeren met de ander en het beheersen van het eigenbelang benadrukt. De mens is een altruïstische actor. De arbeidsrelatie is een giftrelatie. Het is verleidelijk de eerste benadering als negatief te zien, als synoniem aan slecht werkgeverschap en slecht werknemerschap en omgekeerd de tweede als positief, als synoniem aan goed werkgeverschap en goed werknemerschap. Tot op zekere hoogte is dit juist, maar tot in het extreme doorgevoerd zou het leiden tot intenties die we alleen van een heilige kunnen verwachten en niet van een actor in een markteconomie. Noch een puur zakelijke ruilrelatie, noch de relationele giftrelatie leidt tot een duurzame arbeidsrelatie met bestaansrecht op de langere termijn.

Daarna hebben wij ons gericht op (het niveau van) de arbeidsrelatie tussen werkgever en werknemer als basis voor een conceptueel model met een uitwerking voor GWS en GWN. Het model GWS bevat de verwachtingen van de werknemer en omgekeerd bevat het model GWN de verwachtingen van de werkgever. Op deze wijze zijn goed werkgeverschap en goed werknemerschap modelmatig op elkaar betrokken. In feite zijn GWS en GWN een specifieke invulling van de arbeidsrelatie, een bijzonder geval in de zin dat de afstemming en wisselwerking tussen verwachtingen van de werkgever en de werknemer nog kritischer zijn dan in een gewone arbeidsrelatie. Een simpel 'wij-gevoel' is niet voldoende. Oprechtheid in gedrag is van groot belang. Goed werkgeverschap en werknemerschap krijgen gestalte in een dialoog, waarbij partijen zich verplaatsen in de positie van de ander, het is de kunst van het erkennen van de ander. Het model wordt ten slotte gecomplementeerd met indicatoren om de effecten van GWS en GWN op de organisatie en de samenleving in beeld te brengen.

\section{Literatuur}

Akerlof, G. (1982). Labor contracts as a partial gift exchange. Quarterly Journal of Economics, 97(4): 543-569.

Bateman, T.S. \& D.W. Organ (1983). Job satisfaction and the good soldier: The relationship between affect and employee citizenship. Academy of Management Journal, 26: 587-595.

Bolweg, J.F. (1997). De onmogelijkheid van consistent sociaal beleid. Deventer: Kluwer.

Brink, B.E.H. ten \& J.J. van Muijen (2000). Psychologisch contract en binding. In: P.L. Koopman, N.J. Kolk, F. Luijk \& J.J. van Muijen (red.). Boven het maaiveld. Amsterdam: Nieuwezijds, pp. 125-136.

Brockner, J. \& P. Siegel (1996). Understanding the interaction between procedural and distributive justice: the role of trust. In: R.M. Kramer \& R.T. Tyler (1996). Trust in organization. London: Sage, pp. 390-413.

Clark, M.S. \& J. Mills (1979), Interpersonal attraction in exchange and communal relationships. Journal of Personality and Social Psychology, 37: 12-24.

Comer, D.R. (1995), A model of social loafing in real work groups. Human Relations, 48(6): 647-666.

Crouch, C. (1994). Industrial relations and European state traditions. Oxford: Oxford University Press.

Dietz, G. (2004). Partnership and the development of trust in British workplaces. Human Resource Management Journal, 14(1): 1-20.

Fishbein, M. \& I. Ajzen (1975). Belief, attitude, intention and behaviour. An introduction to theory and research. Reading, MA: Addison-Wesley.

George, J. M. \& A. Brief (1992). Feeling good doing good: A conceptual analysis of the mood at work-organizational spontaneity relationship. Psychological Bulletin, 112: 310-329.

Goudswaard, A., R. Gründemann, M. van de Bovenkamp, R. Jongkind, M. Miedema, P. 
Oeij, K. Thé \& C. van de Ven (2004). Visies op goed werkgeverschap en goed werknemerschap. Verslag van interviews met koploperbedrijven(werkdocument). Hoofddorp: TNO Arbeid. Publ.nr. 018-35026/R0416088.

Gründemann, R.W.M. \& E.J. van Dalen (2002). Sectorspecifieke aspecten van personeelsbeleid. Hoofddorp: TNO Arbeid.

Heerma van Voss, G.J.J. (1999). Goed werkgeverschap als bron van vernieuwing van het arbeidsrecht. Deventer: Kluwer.

Herriot, P. (2001). The employment relationship. A psychological perspective. Hove, East Sussex: Routledge.

Huiskamp, R. (2003). Arbeidsrelaties en onderneming. Utrecht: Lemma.

Huiskamp, R. \& F. Kluytmans (2003). Tussen arbeidsrelaties en opdrachtrelaties: dilemma's voor HRM. Tijdschrift voor HRM, 4: 9-30.

Jensen, M.C. \& W.H. Meckling (1976). Theory of the firm: managerial behavior, agency costs and ownership structure. Journal of Financial economics, 3: 305-360.

Katz, D. (1964). The motivational basis of organizational behavior. Behavioral Science, 9: 131-146.

Kluytmans, F. (1999). Arbeidsrelaties tussen schijn en werkelijkheid. Deventer: Kluwer.

Langedijk, M.C. (1998). Flexibel belonen: de keuze voor arbeidsvoorwaarden op maat. Assen: Van Gorcum.

Lepak, D.P \& S.A. Snell (2002). Examining the Human Resource Architecture: the relationships among human capital, employment and Human Resource configurations. Journal of Management, 28(4): 517-543.

Misra, A.K. (1996). Organizational responses to crises: the centrality of trust. In: R.M. Kramer \& T.R. Tyler. Trust in organizations. London: Sage, pp. 261-287.

Mühlau, P. (2000). The Governance of the employment relation, a relational signaling perspective. (Proefschrift). Groningen: Rijksuniversiteit Groningen.

Oeij, P.R.A., R. Huiskamp, A. Goudswaard, T. Kwakkelstein \& A. Nauta (2005). Samen afspraken maken over arbeidsrelaties: mythe of werkelijkheid? MÆO Tijdschrift voor Management et Organisatie, 1: 25-40

Paauwe, J. (2004). HRM and performance. Oxford: Oxford University Press.

Porter, L.W., E.E. Lawler III \& J.R. Hackman
(1996) Ways groups influence individual work effectiveness. In: R.M. Steers, L.W. Porter \& G.A. Bigley (eds). Motivation and leadership at work. New York: McGrawHill, p. 346-354.

Schein, E.H. (1980). Organizational Psychology. Engelwood Cliffs NJ: Prentice Hall.

Sennett, R. (2003). Respect. The formation of character in an age of inequality. New York: Norton.

Robinson, S.L., M.S. Kraatz \& D.M. Rousseau (1994). Changing obligations and the psychological contract: a longitudinal study. Academy of Management Journal, 34: 137152.

Rousseau, D.M. (1995). Psychological contracts in organizations. Thousand Oaks/London: Sage.

Teurlings, W. (2002). Van laatste redmiddel tot goed gemotiveerde eis: een gebruiksaanwijzing voor Goed Werkgeverschap. Mens (en) werk, 3 (1): 10-12.

VanDyne, L. \& J.A. LePine (1998), Helping and voice extra role behaviors: evidence of construct and predictive validity. Academy of Management Journal, 41: 108-119.

Bateman, T.S. \& D.W. Organ (1983). Job satisfaction and the good soldier: The relationship between affect and employee 'citizenship'. Academy of Management Journal, 26: 587-595.

Vries, G. de (1995). De ontwikkeling van de wetenschap. Groningen: Wolters Noordhoff.

Wit, M.A.C. de (1999). Het goed werkgeverschap als intermediair van normen in het arbeidsrecht. (Proefschrift). Tilburg: Universiteit van Tilburg. 